\title{
THE ROLE OF THE EUROPEAN UNION IN CONFLICT RESOLUTION IN AFRICA: TOWARDS COMPREHENSIVE, INTEGRATED AND LONG-TERM COMMITMENT?
}

Since the end of the Cold War, conflict resolution and management, conflict prevention and post-conflict rebuilding have risen to the top of the international agenda and have become core objectives of the EU's relations with Africa. The European Union is increasingly engaged in conflict resolution in Africa.

One of the topics that dominated the agenda of the $4^{\text {th }}$ EU-Africa Summit which took place in Brussels on 2-3 April 2014 and brought together the Heads of State and Government of the European Union member states and Africa, as well as the Presidents of the European Council, European Commission and the African Union, was how to ensure that the EU effectively contributes to conflict resolution in Africa, and how to enhance EU support for African capacities to manage security on the continent with a view to invest in "People, Prosperity and Peace." The 2014 summit offered another opportunity to take a fresh look at the EU-Africa partnership, to highlight some of the results that have been achieved, and to explore areas for future cooperation. ${ }^{1}$

The Summit, given recent developments in Mali, South Sudan and the Central African Republic was expected to enhance the EU-Africa security partnership and to be an important testing ground for the EU's commitment to conflict resolution in Africa. On the margins of the Summit, a special "high-level" meeting on the Central African Republic was held.

Conflict remains one of the most characteristic features of the African continent, and the proliferation of conflicts in the past few years presented the European Union and its member states with many significant challenges. It affected the security context within which the EU-Africa partnership has been conducted so far under the Cotonou agreement and other instruments including the 2005 EU Strategy for Africa and the 2007 Joint Africa-EU Strategy. The long-standing engagement of the European Union in Africa and the EU's commitment to conflict resolution have been severely tested by the escalation of the crises in Mali and, most recently, in the Central African Republic, and highlighted the need to redefine the EU's foreign policy objectives, choices and engagement in conflict resolution in Africa.

1 The first EU-Africa summit was held in Cairo in April 2000, the next in Lisbon in 2007 and third in Tripoli in 2010. The fifth summit will take place in Africa in 2017. 
Even though the international relations of the European Union have recently been dominated by the events in Ukraine, conflict in Africa remains high on the EU agenda. In her recent speech to the UN Security Council on the cooperation between the EU and the UN in the field of international peace and security, EU High Representative Catherine Aston, strongly advocated the EU's comprehensive approach to conflict resolution and claimed that it has been exemplified in dealing with crises in Africa. She elaborated this by referring to the European Union's engagement in conflicts in Somalia, Mali, Niger and the Central African Republic (Address, 2014).

Indeed, since the beginning of 2014, an EU military operation in the Central African Republic and an Election Observation Mission (EOM) in Guinea Bissau have been launched and the European Union Training Mission (EUTM) in Somalia has started its training activities in Mogadishu. A high level meeting on the Central African Republic was held and the EU adopted a strategy on the Gulf of Guinea, and a number of Council conclusions (on South Sudan, the Central African Republic, on the Gulf of Guinea, on Sahel), appointed a new Mission Commander for the EU training mission in Mali and issued a dozen or so statements on the situation in several African countries: Zimbabwe, Niger, South Sudan to name but a few. Africa was also high on the agenda of the Foreign Affairs Council on March 17 (Gulf of Guinea, EU-Africa summit). The EU's unusual activism may, perhaps, be attributed to its preparations for the EU-Africa summit in April, but it may be indicative of the growing importance given to the EU's engagement in African conflict situations as well.

The overall aim of this article is to provide an insight into EU's engagement and increasing role in conflict resolution in Africa and to assess whether, and by what means EU's normative and rhetoric commitment to conflict resolution in Africa can be honoured. The overarching question addressed in this article is about the nature and scope of this commitment, its constitutive elements and different ways in which the European Union is committed to conflict resolution in Africa. To delineate EU's commitment, the article will use, as a convenient starting point of analysis, a statement included in the 2003 European Security Strategy document providing that "if we are to make a contribution that matches our potential, we need to be more active, more coherent and more capable. And we need to work with others." (European Security Strategy, 2003: 11).

The article is set out in four parts. This introductory part sets out a conceptual framework of analysis. The following part provides an up-to-date analysis of the instruments committing the European Union to conflict resolution in Africa with a view to define and delimit, contextualize and measure its normative density. It takes a closer look at both unilateral instruments of the EU as well as those originating from the Union's contractual relations with its African partners. The following part has been designed to address controversies generated by normative, vertical and horizontal, geographical and functional fragmentation of the EU's commitment to conflict resolution in Africa. The final part concludes by commenting on the need to move away from fragmentation towards a more comprehensive, integrated long-term EU commitment regime. The article will consider whether the EU-Africa partnership is, or is not moving in this direction.

This article is based on the assumption that the EU's involvement in conflict resolution in Africa must be seen not only in terms of pursuing self-interest by the EU and its 
member states, but as part of "a wider agenda for peace, justice and equality, where power and politics are supplanted by an institutionalized framework to support dialogue and enhance the achievement of core values, including democracy and the rule of law" (Farrell, 2006: 16). The article will address some of the conceptual problems associated with the EU's role in conflict resolution in Africa. The conceptualization of the EU as a conflict resolution provider or facilitator will test the assumption that "the European Union favours the use of soft powering order to exert influence on the international stage" (ibidem: 17) and that it may be seen as an alternative 'soft', 'civilian' or 'normative' power in its involvement in conflict resolution in Africa. A growing body of literature defines EU's foreign policy in terms of 'civilian' or 'normative' power and argues that the EU's commitment to 'civilian', economic and political rather than military means and capabilities constitutes its differentia specifica and makes it a special international actor and security provider. ${ }^{2}$ This is where the European Union differs from other 'hard' security providers like NATO.

The paper aims at capturing the role of the European Union itself as either an actor in its own right and/or as a framework for conflict resolution, acknowledging at the same time the often predominant role of individual member states, particularly those with traditional vested interests in Africa.

Conflict resolution has become a prominent topic in the study of the European Union and a very active research subject-area, also in Poland. ${ }^{3}$ Much has been written about EU's ability, or inability, to contribute to conflict resolution in European neighbourhood (Tocci, 2007) or border conflicts (Diez et al., 2008) e.g. in relation to the conflict in Yugoslavia, the Cyprus problem, Georgia or the Middle East. There is also a growing body of scholarship and literature focusing on EU's relations with Africa, including conflict resolution in the African context. The EU's engagement in conflict resolution in Africa has generated a wide range of research focused on its nature and effects. $^{4}$

There is no definitional/terminological clarity concerning the role of the EU in dealing with conflict in Africa. Even a cursory survey of the relevant instruments and literature reveals no precise, consistent usage of terminology. 'Conflict management', 'conflict resolution', 'conflict prevention', 'conflict/dispute settlement', 'mitigation or prevention of escalation of conflict' 'conflict prevention, peace building and mediation' and many other related terms are being used at both normative and rhetoric level. And

2 See: I. Manners, Normative Power Europe: A Contradiction in Terms, "Journal of Common Market Studies", Vol. 6, No. 2, pp. 235-258; I. Manners, Normative Power Europe Reconsidered: Beyond the Crossroads, in: Civilian or Military Power European Foreign Policy in Perspective, (ed.) H. Sjursen, London 2007.

The role of the European Union in conflict resolution in Africa was, for instance prominently present at the latest, annual international conference "Europe in the XXI Century" organized by the Adam Mickiewicz University. Słubice, 6-7 February 2014.

${ }^{4}$ See for instance: Responding to Conflict in Africa. The United Nations and Regional Organizations, (ed.) J. Boulden, New York 2013; A. Nhema, P. T. Zeleza, The Resolution of African Conflicts. The management of Conflict Resolution and Post-conflict Reconstruction, Addis Ababa-Oxford-Pretoria 2008; EU Conflict Prevention and Crisis management. Roles, Institutions and Policies, (eds.) E. Gross, A. E. Jucos, London 2011; R. Zięba, International Roles of the European Union, "Rocznik Integracji Europejskiej” 2012, No. 6, pp. 63-78. 
the meanings attached to those different terms may vary. For the purposes of the present analysis the term 'conflict resolution' will be used as a collective term referring to the expected outcome of the EU's engagement in African conflict - the end of the conflict, its 'resolution' and the steps that need to be taken to that end including conflict prevention and management. The border lines between conflict prevention, management or resolution are often blurred and not always easy to determine. Precisely for that reason, the focus here is on EU's activities aiming at ending already existing conflicts (for more on proliferation of terms: Smith, 2009: 180). Conflicts, the European Union helps to resolve may be either inter-state or intra-state or a combination of both.

Special attention will be given to normative commitments made by the European Union towards 'one Africa' with reference to the 2005 EU Strategy on Africa and the 2007 Joint EU-Africa Strategy. However, the paper cannot ignore and put aside regulations concerning EU's relations with sub-Saharan Africa, especially the Cotonou agreement, or EU's relations with North Africa, based on the Euro-Mediterranean Partnership and the Union for the Mediterranean and the European Neighbourhood Policy.

Another clarification that needs to be made here is that this article is primarily concerned with the CFSP /CDSP and CFSP/CDSP related diplomatic instruments and activities carried out under the overall authority of the High Representative for Foreign Affairs and Security Policy. It acknowledges, however, the importance of moving beyond the CSDP framework to explore the broader range of security instruments that the EU has at its disposal.

This article argues for a multi-dimensional, integrated approach to understanding EU's role in conflict resolution in Africa and suggests the need to move beyond the traditional rhetoric of external Europeanization, including the "export of European values", towards a more neutral description of EU's role as an "interregional partner", "global actor", "role model" or "positive force in world politics". This paper places the EU's engagement in conflict resolution in Africa in its rich normative and historical context while assessing its achievements, failures and prospects for the future.

\section{EU NORMATIVE COMMITMENT TO CONFLICT RESOLUTION IN AFRICA}

The main purpose of this part is to map the territory: to identify the sources of the EU's commitment to conflict resolution in Africa and to determine what exactly they commit the European Union to. In other words, this part attempts to explain how the European Union has obtained the competence to be engaged in conflict resolution in Africa, which African actors the European Union is expected to assist and by what means.

EU's commitment to conflict resolution in Africa is embodied in an expanding anthology of international and EU instruments of different character and significance. Their identification or even acknowledgement may not always be easy. A proposed taxonomy of instruments committing the European Union to conflict resolution in Africa will reflect their nature (i. e. whether they are EU's own instruments or international 
treaties or other international instruments of bilateral or multilateral character), hierarchy and chronology.

The roots of the EU's engagement in conflict resolution beyond its borders are to be found in the EU Treaties, in international agreements concluded by the European Union and in its own acts, both legislative and non-legislative, and authoritative decisions.

A short reference to the EU Treaties makes a good starting point. Art. 11 of the Treaty on European Union (TEU) provided that among the foreign and security policy objectives of the Union were "to strengthen the security of the Union in all ways" and "to preserve peace and strengthen international security, in accordance with the principles of the United Nations Charter, as well as the principles of the Helsinki Final Act and the objectives of the Paris Charter, including those on external borders." The Maastricht Treaty enabled the EU to move beyond its borders in tackling security concerns to Africa in the neighbouring South (ENP, Euro-Mediterranean) and the distant South (ACP). Art. 11 has been amended by the treaty of Lisbon, which was signed on 13 December 2007 and entered into force on 1 December 2009, and is now Art. 21. Art. 21.2 stipulates, inter alia, that "The Union shall define and pursue common policies and actions," and shall work for a high degree of cooperation in all fields of international relations, in order to:

"(c) preserve peace, prevent conflicts and strengthen international security, in accordance with the purposes and principles of the United Nations Charter, with the principles of the Helsinki Final Act and with the aims of the Charter of Paris, including those relating to external borders" (Lisbon Treaty, 2012).

Conflict prevention has, therefore, been explicitly mentioned as one of the EU's foreign policy objectives. Another interesting provision of the Lisbon Treaty (Zwolski, 2012) relevant to our analysis, provides that the "The Union shall seek to develop relations and build partnerships with third countries, and international, regional or global organizations" which share the principles of the Union and that that Union shall promote "multilateral solutions to common problems, in particular in the framework of the United Nations."

The boundaries of the EU's involvement in conflict resolution in Africa have been demarcated by a network of international agreements concluded by the EU with its African partners: the African Union, the Southern African Development Community (SADC), the Economic Community of West African States (ECOWAS), other regional integration organizations in Africa and many of their member states (Economic Partnership Agreements). However, the central piece of regulation is provided by the Cotonou Partnership Agreement signed between the European Community and its member states, and 79 ACP states, most of which are from sub-Saharan Africa, on 23 June 2000. Since 2000, it has been the framework for their mutual relations and a basis for EU's conflict resolution related activities in sub-Saharan Africa.

Relations with North African, Mediterranean states are subject to yet another set of regulations embodied, primarily, in the European Neighbourhood Policy (ENP) instruments: the 1995 Barcelona Declaration establishing the Euro-Mediterranean Partnership and its revised version - the Union for the Mediterranean - a partnership of the EU member states and 15 Mediterranean, including North African, states. 
As far as the EU's 'own' instruments are concerned, special attention must be given to a series of EU common strategies, including the most general the 2005 EU Strategy on Africa, and other strategies such as the 2000 Common Strategy on the Mediterranean Region, the 2011 EU Strategy for Security and Development in the Sahel, and very recently adopted by the Council of the European Union, the EU strategy on the Gulf of Guinea.

A large number of EU legislative acts and authoritative decisions form an integral part of the normative framework within which EU's commitment to conflict resolution in Africa is shaped, articulated and implemented. Numerous common positions and joint actions have been adopted with respect to conflict in Africa. The first was the Joint Action towards South Africa (concerning support for the transition towards a democratic and multi-racial South Africa) adopted by the Council in 1993. In 1999-2000 the Council adopted five common positions on the conflict between Ethiopia and Eritrea, in 2001 a Common Position on combating the illicit traffic in conflict diamonds, as a contribution to prevention and settlement of conflicts, and in 2009 a Common Position on restrictive measures against Zimbabwe. However, of particular importance for the EU's commitment to conflict resolution in Africa is the Council Common Position 2005/304/CFSP concerning conflict prevention, management and resolution in Africa, adopted on 12 April 2005. Finally, EU legislation reflecting its commitment to conflict resolution in Africa embodies a large number of Council decisions and regulations and Political and Security Committee decisions such as the recently (14 January 2014) adopted Decision extending the mandate of the Head of Mission of the European Union CSDP mission in Niger (EUCAP Sahel Niger).

Yet another category of the EU's own instruments are the so-called 'Council conclusions' adopted on a regular basis by the Council of the European Union in its Foreign Affairs formation. Council conclusions on South Sudan, on Sahel, on the Central African Republic, and on the Gulf of Guinea were adopted in 2014 alone.

The EU's commitment to conflict resolution in Africa and its willingness to work to that end with its African partners have been repeatedly reiterated by a number of European Councils. The Essen European Council in December 1994, for instance, strongly advocated "an intensive political dialogue between the European Union and the Organization for African Unity (OAU) in particular regarding conflict prevention in Africa" (Essen European Council, 1994). The Madrid European Council in December 1995 confirmed the readiness of the European Union "to support African efforts in the field of preventive diplomacy and peacekeeping" and recognized "the importance of the African lead in preventive diplomacy and conflict resolution in Africa" (Madrid European Council, 1995: annex 13). The most recent European Council held in Brussels in March 2014, ahead of the $4^{\text {th }}$ EU-Africa Summit, reiterated that "the European Union remains committed to building a partnership of equals with Africa and strengthening relations in all relevant areas in response to the growing interdependence between the European Union and Africa." The Council has also emphasized its support for African partners in the area of security and promised that "the Union will continue to provide operational support through its civilian crisis management missions and military operations, at the request of individual countries and in close cooperation with other regional and international actors" (Brussels European Council, 2014). 
Finally, a string of daily statements made by or on behalf of the EU High Representative for Foreign Affairs and Security Policy and declarations made by the High Representative "on behalf of the European Union" on the situation in different parts of Africa (e.g. a statement of 27 March 2014 on the extremely grave situation in the Central African Republic) complements EU legislative and policy instruments.

All of the instruments mentioned above, as well as regimes and institutions they have created, help us to construct the European Union's policy on conflict resolution in Africa and to determine the character and the scope of its commitment thereto. However, the instruments listed above are of different character and normative significance. Most of them just re-cite what the leading instruments have committed the European Union to. Therefore, a more detailed analysis of the leading instruments could, perhaps, help us to answer the question this article is focused on namely: is the European Union moving towards a comprehensive, integrated and long-term commitment to conflict resolution in Africa?

The four instruments, more detailed analysis of which may help to answer this question, in chronological order, are: the Cotonou Agreement, the Council Common Position concerning conflict prevention, management and resolution in Africa, the $E U$ Strategy on Africa and the Joint Africa-EU Strategy.

\section{The Cotonou Agreement}

Relations between the European Union and most of the African states are governed by the Partnership Agreement between 79 members of the African, Caribbean and Pacific group of states on one side, and the European Community and its member states on the other side. The Agreement was signed in Cotonou in Benin, on 23 June 2000, for twenty years. The Cotonou Agreement has been revised twice - in 2005 and 2010 and all the new members of the European Union are parties to the Agreement. (South Africa, while a signatory of the Cotonou Agreement, concluded a separate Trade, Development and Cooperation Agreement with the European Union and its member states).

The primary objective of the ACP-EC partnership is to promote and expedite the economic, cultural and social development of the ACP States, poverty eradication, sustainable development, and progressive integration of the ACP countries into the world economy with a view to contributing to peace and security.

An important component of the Agreement and partnership it has established, is the so-called political dialogue focusing on issues of mutual concern and carried out by the parties in conformity with policies "to promote peace and to prevent, manage and resolve violent conflicts" (Art. 8). Art. 11, dealing with peace-building policies, conflict prevention and resolution, obliges the parties to "pursue an active, comprehensive and integrated policy of peace-building and conflict prevention and resolution within the framework of the Partnership" and stipulates that this policy "shall be based on the principle of ownership," and provide support for "mediation, negotiation and reconciliation efforts." Finally, "in situations of violent conflict the Parties shall take all suitable action to prevent an intensification of violence, to limit its territorial spread, and to facilitate a peaceful settlement of the existing disputes" (Cotonou Agreement, 2000). 
The Cotonou Agreement represents an important step in defining the role of the European Union in conflict resolution, and also conflict prevention and management, in Africa. The Agreement provides a comprehensive framework for an active role of the EU in the political dialogue between the parties. It also presents the Partnership, like the European Union itself, as a peace project.

\section{Council Common Position Concerning Conflict Prevention, Management and Resolution in Africa}

The Council Common Position 2005/304/CFSP concerning conflict prevention, management and resolution in Africa of 12 April 2005 is the third, revised version of this document. The previous versions were adopted by the Council in 1997 and in 2001. The document, in its preamble, strongly emphasizes that the primary responsibility for prevention, management and resolution of conflicts on the African continent lies with Africans themselves and that the central actors in the prevention, management and resolution of conflicts in Africa are the African Union and African sub regional organizations, such as the Economic Community of West African States, the South African Development Community and the Intergovernmental Authority on Development (IGAD), the Economic Community of Central African States (ECCAS) and the Economic and Monetary Community of Central Africa (CEMAC). The role of the European Union in conflict resolution in Africa is defined in Art. 1 providing that:

\footnotetext{
"The EU shall contribute to the prevention, management and resolution of violent conflicts in Africa by strengthening African capacity and means of action in this field, in particular through enhanced dialogue with, and support for, the AU and sub-regional organisations and initiatives, and civil society organisations."
}

Elsewhere, the document explains that the EU actions shall cover conflict prevention, crisis management, peace-building and reconstruction of post-conflict states. Another important provision authorizing the European Union and its member states to enhance the African "peace support operations capabilities, at regional, sub-regional and bilateral levels," stipulates, that "notwithstanding its commitment to African ownership, EU shall remain prepared to become involved, whenever necessary, in crisis management in Africa with its own capabilities" and, in Art. 6, that:

\footnotetext{
"the EU and its Member States shall continue, on a case-by-case basis, to consider deploying their own operational means for conflict prevention and crisis management in Africa, in accordance with the principles of the Charter of the United Nations and in close cooperation with UN activities in the region."
}

The Common Position repeatedly emphasizes the primary role of the United Nations and international law, as the framework for activities undertaken within the context of prevention, management and resolution of conflicts in Africa. It also makes a reference to the Cotonou Agreement even though, the Common Position itself is exclusively concerned with conflict in Africa. There seems to be no contradiction between the two instruments, both referring to prevention, management and resolution of violent conflict in Africa. The Common Position, however, seems to be much stronger in emphasizing the responsibility of African actors themselves. 


\section{EU Strategy for Africa: Towards a Euro-African Pact to Accelerate Africa's Development}

The 2005 EU Strategy for Africa was designed to initiate a new stage in Euro-Africa Partnership. It was endorsed at the second EU-Africa Summit in Lisbon in 2007 and was meant to complement the revised Cotonou Agreement, the Euro-Mediterranean Partnership and the European Neighbourhood Policy. The document makes a reference to extensive experience of the European Community and its contractual arrangements with different parts of Africa and promises to offer "a comprehensive, integrated and long-term framework for its relations with the African continent."

The Strategy focuses primarily on issues related to development, and more specifically, with the prerequisites for attaining the Millennium Development Goals (MDGs) in Africa. It claims that there can be no sustainable development without peace and security and, consequently, "the EU should step up its efforts to promote peace and security at all stages of the conflict cycle, from conflict prevention, via conflict management to conflict resolution and post-conflict reconstruction" (EU Strategy for Africa, 2005).

In Africa, the Strategy identifies two areas of "chronic conflict and instability": the Mano-River region in West Africa and an area extending from the Horn of Africa to eastern Congo and claims that these two areas "are dominated by a large number of countries in conflict as well as a high proportion of fragile states, i.e. states that - often weakened by endemic crises and conflicts or natural disasters - lack credible, legitimate and/or effective governance" and, therefore, "the ongoing Darfur conflict in Sudan, the 'forgotten war' in northern Uganda, the persistent insecurity in the east and north of the Central African Republic and the instability in eastern Congo remain serious causes for concern."

The Strategy calls for a comprehensive EU approach to "all issues relating to conflict prevention, management and resolution, post-conflict reconstruction and peacebuilding" and promises that the EU will step up its efforts " to promote peace and security at all stages of the conflict cycle" and concludes that "a common EU policy with regard to the different conflicts in Africa is therefore needed."

The Strategy, in line with other, previously analysed instruments, underlines the leading role of the United Nations, the need to explore the synergies between different organizations involved in Africa and gives particular attention to the capacity building plan for the African Union. The Strategy, unlike previous instruments, claims that while Africa has many faces, different histories and diverse needs, it has embarked on a path of integrating the entire continent. The EU Strategy for Africa "will therefore, for the first time, address Africa as one entity."

\section{A Joint Africa-EU Strategy}

The 2007 Africa-EU Strategic Partnership - A Joint Africa-EU Strategy, was adopted by the participants of the second Africa-EU Summit in Lisbon in 2007. The Strategy is intended to provide an overarching long-term framework for Africa-EU relations, a political vision and a roadmap for the future cooperation between the two con- 
tinents. Regular Africa-EU summit meetings, most recently held in Brussels on April 2-3, 2014, form an important component of its institutional architecture.

The importance of the Joint Strategy can be fully appreciated only against the background of previously discussed documents committing the European Union to conflict resolution in Africa. The Joint Strategy is meant to "move away from a traditional relationship and forge a real partnership characterised by equality and the pursuit of common objectives." Indeed, it is rather unusual for the European Union to shape its strategy on a bilateral, or, like in this case, multilateral basis.

The Joint Strategy begins with an observation that Africa and Europe are bound together by history, culture, geography and a common future. It makes a reference to their partnership as a community of values: the respect for human rights, freedom, equality, solidarity, justice, the rule of law and democracy, embodied in the constitutive instrument of both the European Union and the African Union and other international agreements. It describes the European Union as a key partner for African states and organizations who helps to create conditions for lasting peace and stability. More specifically, the Joint Strategy states that:

"the two continents have laid the foundation for successful cooperation based on the need to promote holistic approaches to security, encompassing conflict prevention and long-term peace-building, conflict resolution and post-conflict reconstruction, linked to governance and sustainable development, with a view to addressing the root causes of conflicts" (The Africa-EU Strategic Partnership, 2007: para. 1).

With respect to EU support for promoting peace, security and stability in Africa, the Joint Strategy reiterates the principle of African leadership but at the same time promises to draw 'valuable guidance' from a number of EU instruments concerning conflict resolution in Africa, such as the 2005 EU Concept for Strengthening African Capabilities for the Prevention, Management and Resolution of Conflicts, prepared jointly by the Council General Secretariat and the Commisssion in conjunction with the EU Strategy for Africa, as well as other relevant EU instruments.

In addition, the Joint Strategy identifies the African Union as a natural interlocutor for the European Union on African continental issues and indicates that, consequently, the institutional architecture of the Africa-EU partnership on the Africa side will be centered on the African Union.

The Joint Strategy has, undoubtedly, drawn new contours of the EU-Africa partnership and represents a new forward-looking projection for relations between Europe and Africa. However, whether or not the Joint Strategy might be the main vehicle for enhanced EU-AU partnership, remains to be seen. At the end of the day, the document itself, describes its role as a "framework" and "a political vision". In the meantime, the $4^{\text {th }}$ EU-Africa Summit acknowledged its role as an instrument of the solidarity and commonality of interests between Africa and Europe.

In conclusion, it can be noted that along with the four instruments discussed above in greater detail, both sides of the EU-Africa partnership have produced an already abundant number of documents of different nature and scope and that the process in ongoing. New documents perpetually proliferate and there is ample evidence that the role they assign to the European Union in conflict resolution in Africa has in the last decade undergone profound transformations. The following part attempts to uncover the central features of this evolution. 


\section{BEYOND FRAGMENTATION?}

The 2005 EU Strategy for Africa noted its concern that "for too long the EU's relations with Africa have been too fragmented, both in policy formulation and implementation" and, therefore, its aim was to give the EU a comprehensive, integrated and long-term framework for its relations with the African continent (EU Strategy for Africa, 2005: 2).

Fragmentation, which the EU Strategy makes reference to, applies, no doubt, to the EU's policy formulation and implementation concerning conflict resolution in Africa. Indeed, normative and institutional fragmentation is not a new phenomenon in this field. Karen Smith is absolutely right to suggest that in this field, "a coherent strategy is still more of an objective than a reality" (Smith, 2009: 170).

Fragmentation of the EU's role and normative commitment to conflict resolution in Africa has many different faces. It may refer to the proliferation of instruments regulating the same subject-matter, it is horizontal and vertical, institutional, functional de facto or de jure, permanent or temporary.

The EU's policy towards conflict resolution in Africa has been reflected in a multitude of instruments produced over the past decade. An ever-increasing number of EU normative commitments of some sort, towards Africa at large, or particular African partners, states and African organizations alike, have been formulated in an ever increasing number of instruments. Consequently, "there remains a clear tension between the different policy approaches of the EU towards Africa" (Hurt, 2004: 170). No real attempt has been made so far either to chart and delineate a network of instruments that commit the European Union to conflict resolution in Africa or to systematically outline the normative evolution of the EU's commitment thereto. They seem to form a loose collection of instruments rather than a vertically and horizontally coherent system of norms, even though the European Union gives considerable weight to its prior acts. The remedy could be the organization of proliferating documents into clearer hierarchies.

In addition to the problem of proliferation of instruments there are a number of other intractable questions that need to be addressed by both policymakers and academics. Among the most conspicuous is the question of normative effects of instruments committing the European Union to conflict resolution in Africa and their vertical fragmentation.

The prospect of normative conflict between different levels of regulation of the same subject-area and adopted at different times remains real. It is true that the EU's approach to conflict resolution in Africa is based on hard international law commitments embodied in a number of international treaties concluded by the European Union and its member states, such as the Cotonou Agreement, and agreements with African regional economic communities (RECs) and many of their members. But, at the same time, it is embodied in a large number of other instruments of varying normative and legal value adopted either by the European Union itself, such as the 2005 EU Strategy for Africa, or originating from high level meetings between the representatives of the European Union and its member states and their African partners, such as the 2007 Joint EU-Africa Strategy. Most of them can be described as policy instruments playing a constitutive role in the field under consideration. A comment by Mary Farrell adds yet another aspect to this question of normative fragmentation: 
"in practice, the same policy approach is not adopted for all regional groupings and for individual countries, so that the EU's effectiveness as a norm exporter is determined by the nature of each arrangement and how the target region responds to the EU. Agreements that are politically rather than legally binding tend to commit the contracting parties only if there is a strong interest at stake" (Farrell, 2009: 1170).

How can, for instance, the recognition of 'One Africa' embodied in the $2005 E U$ Strategy for Africa be reconciled with the differentiation and regionalization principle - one of the fundamental principles of the Cotonou Agreement? The promotion of regionalism has indeed been a consistent and distinctive feature of EU relations with Africa. ${ }^{5}$ What it calls for is internal coherence and better coordination between the EU strategies and other existing cooperation frameworks and instruments between the EU and its African Partners.

Another concern is that the EU's contractual arrangements with Africa are horizontally fragmented: Cotonou Agreement for sub-Saharan states, ENP/Union for the Mediterranean for Northern Africa, TDCA/DCI for South Africa. The EU continues to work with as many African actors as possible. Alvaro de Soto, an experienced UN negotiator commented that in his view "in the field of conflict management, additions subtract, and collective diplomacy is by and large a contradiction in terms" (de Soto, 2012: XV). The EU's commitment to conflict resolution in different parts of Africa is of different character and density. It is very likely to lead to the emergence of specialized and even relatively autonomous rules or sets of rules and legal institutions. The strongest, at least normatively, and challenging seems to be the commitment based on the European Neighbourhood Policy. In her recent speech to the European Parliament, Catherine Ashton described EU relations with the Southern Neighbourhood as particularly challenging.

Yet another issue is inter-institutional fragmentation related to EU's relations with a large number of African partners. The inter-institutional coherence has been substantially enhanced by the recognition of the African Union as the main interlocutor of the European Union in Africa. A recently adopted 'roadmap' of the $4^{\text {th }}$ EU-Africa Summit refers, however, to rather unspecified "continent to continent" relationship.

A related question is about EU's own highly complex, fragmented system of institutions and competences in the field of conflict resolution. Cremona, for instance, points out that "a fragmentary approach" is adopted towards provisions structuring the Union's relationship with different groups of third countries and that the Treaty of Lisbon "perpetuates and even extends a tendency to define new legal bases for different categories of relationship" (Cremona, 2010: 50). Cameron, commenting on the establishment of the European External Action Service concludes that "it remains to be seen whether this institutional innovation can address the challenges that have constrained the EU's role in conflict prevention so far, including the EU's lack of coherence, consensus, conceptual clarity and ambition." Elsewhere, and with reference to the European Union's competence in the field of conflict prevention and resolution, Cameron

5 See: Regional Organizations in African Security, eds. F. Sörerbaum, R. Tavares, London 2011; M. Farrell, EU Policy Towards Other Regions: Policy Learning in the External Promotion of Regional Integration, "Journal of European Public Policy" 2009, Vol. 16, No. 8, pp. 1165-1184; EU External Governance. Projecting EU Rules beyond Membership, eds. S. Lavenex, F. Schimmelfennig, London 2010. 
suggests that "a coherent preventive approach to conflict and crisis depends on three factors: a clear definition of objectives, capacity to act, and the political will to act" (Cameron, 2012: 211-212). Karen Smith too, notes that "conflict prevention is still not fully integrated into policy-making" and, consequently "conflict-prevention policy exposes the weaknesses of the EU's foreign policy system, such as the turf wars engendered by the pillar division" (Smith, 2009: 179). Smith, at the same time concludes that "in many ways, the EU conflict prevention efforts are unique" because "it can muster a large conflict prevention 'toolbox', much more so than any other international organization and, arguably, more so than the individual member states" (ibidem: 202).

Additionally, Wong rightly identifies as yet another weakness of the European Union, the fact that "there are attempts by member states, either individually or in groups, to push the EU in certain general directions" (Wong, 2011: 152). Similarly, Olsen explains that "internal disagreements, on the one hand between member states and on the other hand between member states and the European Commission, have had a considerable impact on the policy initiatives directed towards Africa" (Olsen, 2005: 138). Tocci, who considers conflict resolution as inextricably tied to the EU's very emergence and raison d' être, comes to the conclusion that with respect to conflict resolution "what the EU aspires to achieve, how it has articulated its policies, and what it's strengths, weaknesses and future prospects are, are all inextricably tied to what the Union is and what it represents" (Tocci, 2012: 134).

As far as the African institutional side of the equation is concerned, its description as 'fragmented' would, perhaps, be rather euphemistic. Akokpari argues that "while the AU has set out good intentions and is theoretically committed to conflict resolution, its record in this area has been remarkably unimpressive" (Akokpari, 2012: 151). Okoth attributes weak performance of the OAU/AU to three categories of weaknesses: institutional, structural and historical (Okoth, 2008: 22-23).

This part has demonstrated a number of contentious aspects originating from the fact that the EU's commitment to conflict resolution in Africa is embodied in a multitude of normative instruments or normative layers. It is easy to exaggerate the negative consequences of normative fragmentation. Indeed, normative fragmentation, in all of its many forms, is commonly seen as an unwelcome departure from "legal excellence" especially when it leads to contradictions and conflict between declared rules and between declared rules and actual actions. Rummel noted this long ago claiming that "EU member states are not yet prepared to take on, in practical terms, the wider responsibility they talk about in their official documents" (Rummel, 1997: 115).

Obviously, such accumulation of normative instruments, as in our case, may be difficult to manage. Fragmentation, however, can be seen more favourably, when flexibility and differentiation outweigh uniformity. The EU-Africa partnership requires both, and some degree of fragmentation, or differentiation may have positive aspects, if properly justified.

The participants of the $4^{\text {th }}$ EU-Africa Summit held in Brussels earlier this month agreed to take steps towards enhanced integration of the two continents and reiterated that the EU's enhanced commitment to conflict resolution in Africa continues to consti- 
tute an inherent component of this plan. The Summit covered a range of different issues and adopted a final declaration, a declaration on migration and mobility and a document called "roadmap" that sets out a list of strategic priorities of the EU-Africa partnership and identifies the means for their implementation before the next summit in 2017. The Summit did not produce any new strategic document. Instead, it reaffirmed its commitment to the 2007 Joint EU-Africa Strategy.

The Declaration underlines the importance of addressing all aspects of the conflict cycle, from preventive action to post-conflict reconstruction and development and explicitly refers to the EU commitment to:

"work in close collaboration with Africa, in the framework of the APSA, in support of
African led peace operations and, more generally, African efforts in areas like Secu-
rity Sector Reform, Border Management, Peacebuilding or Post-Conflict Reconstruc-
tion or Reconciliation, through the provision of advice, mentoring and training. In
addition, the supply of equipment is an option, either as a complement to CSDP mis-
sions and operations or as part of stand-alone measures" (EU-Africa Summit Declara-
tion: para. 12).

The Roadmap was adopted to provide a framework for "continent to continent" cooperation and political dialogue of inter-regional, continental and global dimensions, wherever Africa and the European Union have mutual interests. Special status in this process was granted to the AU Peace and Security Council and the EU Political and Security Committee (EU-Africa Summit Roadmap, 2014-2017: para. 4).

This article has demonstrated that the EU's engagement in conflict resolution in Africa has evolved from a relatively limited scale into a comprehensive system of normative instruments and institutions. It has expanded in scope and deepened in intensity and density. For the European Union, the challenge ahead is to find a balance between the need for diversity in its relations with various African partners and the need of maintaining an overall, coherent and long-term framework of engagement in conflict resolution in Africa. The reality is that both policy models are equally important and not mutually exclusive. There has been some progress, albeit modest, in diminishing the inequality or imbalance in terms of available tools, instrument and policies for conflict prevention, management and resolution between European and African partners. It remains to be seen whether the necessary tools for a meaningful and realistic compromise acceptable to both partners can be found and the principle of ownership respected. At the end of the day, what really matters is that conflicts that remain unresolved and continue to have serious implications for peace and security in Africa and beyond are resolved, or at least managed in some way.

\section{Bibliography}

Address by the EU High Representative Catherine Ashton at the UN Security Council on the cooperation between the EU and the UN on international peace and security (2014), New York, 14 February.

Akokpari, J. (2012), Limited Capabilities, Great Expectations. The African Union and Regional Conflict Management, in: Conflict Management in Divided Societies. Theories and Practice, (eds.) S. Wolff, C. Yakinthou, London. 
Brussels European Council. Conclusions (2014), 20-21 March.

Cameron F. (2012), An Introduction to European Foreign Policy, $2^{\text {nd }}$ edition, London.

Cotonou Agreement: Partnership Agreement between the Members of the African, Caribbean and Pacific Group of States of the One Part, and the European Community and its Member States, of the Other Part, signed in Cotonou on 23 June 2000 (2000), Official Journal L 317, 15 December.

Council Common Position 2005/304/CFSP of 12 April 2005 concerning conflict prevention, management and resolution in Africa (2005), Official Journal L 97, 15 April.

Cremona M. (2010), Defining Competence in EU External Relations: Lessons from the Treaty Reform Process, in: Law and Practice of EU External Relations. Salient Features of a Changing Landscape, (eds.) A. Dashwood, M. Maresceau, Cambridge.

Essen European Council. Presidency Conclusions (1994), 9-10 December.

European Security Strategy 2003. A Secure Europe in a Better World. European Security Strategy (2003), Brussels.

EU Strategy for Africa. Towards a Euro-African pact to accelerate Africa's Development (2005), Brussels.

Farrell M. (2006), A Triumph of Realism over Idealism? Cooperation Between the European Union and Africa, in: Fourth EU-Africa Summit Declaration, Roadmap 2014-2017 (2014), Brussels, 2-3 April.

Farrel M. (2009), EU Policy Towards Other Regions: Policy Learning in the External Promotion of Regional Integration, "Journal of European Public Policy", Vol. 16, No. 8.

Gross E., Juncos A.E. (2011), EU Conflict Prevention and Crisis Management. Roles, Institutions and Policies, London.

International Relations and the European Union (2011), (eds.) C. Hill, M. Smith, $2^{\text {nd }}$ edition, Oxford.

Hurt S.R. (2004), The European Union's External Relations with Africa after the Cold War, in: Africa in International Politics. External Involvement on the Continent, (eds.) I. Taylor, P. Williams, London.

Madrid European Council. Presidency Conclusions (1995), 15-16 December.

Manners I. (2002), Normative Power Europe: A Contradiction in Terms, "Journal of Common Market Studies", Vol. 6, No. 2.

Manners I. (2007), Normative Power Europe Reconsidered: Beyond the Crossroads, in: Civilian or Military Power European Foreign Policy in Perspective, (ed.) H. Sjursen, London.

Okoth, P.G. (2008), Conflict Resolution in Africa. The Role of the $O A U \&$ the AU, in: The Resolution of African Conflicts. The Management of Conflict Resolution \& Post-Conflict Reconstruction, (eds.), A. Nhema, P. T. Zeleza, Addis Ababa-Oxford-Athens-Pretoria.

Regional Organizations in African Security (2011), (eds.) F. Söderbaum, R. Tavares, London.

Responding to Conflict in Africa. The United Nations and Regional Organizations (2013), (ed.) J. Boulden, New York.

Rummel R. (1997), The CFSP's Conflict Prevention Policy, in: Common Foreign and Security Policy. The Record and Reforms, (ed.) M. Holland, London.

Smith K.E. (2009) European Union Foreign Policy in a Changing World, $2^{\text {nd }}$ edition, Cambridge.

Soto A. de (2012), Foreword, in: Conflict Management in Divided Societies. Theories and Practice, (eds.) S. Wolff, C. Christalla, London.

The Africa-EU Strategic Partnership. A Joint Africa-EU Strategy (2007), 16344/07, Lisbon, 9 December.

The EU as a Global Player. The Politics of Interregionalism (2006), (eds.) F. Söderbaum, L. van Langenhove, London. 
The European Union and Border Conflicts. The Power of Integration and Association (2008), (eds.) T. Diez, A. Mathias, S. Stetter, Cambridge.

The Resolution of African Conflicts. The Management of Conflict Resolution \& Post-Conflict Reconstruction (2008), (eds.) A. Nhema, P. T. Zeleza, Addis Ababa-Oxford-Athens-Pretoria.

Tocci N. (2007), The EU and Conflict Resolution. Promoting Peace in the Backyard, London.

Treaty on European Union: Consolidated version of the Treaty on European Union, Brussels, 2012.

Wolff S., Yakinthou C. (2012), Conflict Management in Divided Societies. Theories and Practice, London.

Wong R. (2007), The Europeanization of Foreign Policy, in: Europeanization. New Research Agendas, (eds.) P. Graziano, M. P. Vink, Houndmills.

Zięba R. (2012), International Roles of the European Union, "Rocznik Integracji Europejskiej”, No. 6.

Zwolski K. (2012), The EU as an International Security Actor After Lisbon: Finally a Green Light for a Holistic Approach?, "Cooperation and Conflict", Vol. 47, No. 1.

\begin{abstract}
The overall aim of this article is to provide an insight into EU's engagement and increasing role in conflict resolution in Africa. The question addressed in this article is about the nature and scope of this commitment. To that end, this article provides an up-to-date analysis of the instruments committing the European Union to conflict resolution in Africa with a view to define and delimit, contextualize and measure its normative density. It takes a closer look at both unilateral instruments of the EU as well as those originating from the Union's contractual relations with its African partners. It addresses a number of controversies generated by the normative: vertical and horizontal, institutional and functional fragmentation of the EU's commitment to conflict resolution in Africa. The overarching argument presented in this article is that the European Union and its African partners need to move away from their dramatically fragmented partnership toward a more comprehensive, integrated and long-term regime for the EU's engagement in conflict resolution in Africa.
\end{abstract}

\title{
ROLA UNII EUROPEJSKIEJ W ROZWIĄZYWANIU KONFLIKTÓW W AFRYCE - W KIERUNKU PEŁNEGO, ZINTEGROWANEGO I DLUGOTERMINOWEGO ZAANGAŻOWANIA?
}

\section{STRESZCZENIE}

Zasadniczym celem tego artykułu jest problemowe przedstawienie coraz głębszego zaangażowania Unii Europejskiej w rozwiązywanie konfliktów w Afryce. Opracowanie koncentruje sie na badaniu charakteru i zakresu tego zaangażowania. W tym celu autor podejmuje analizę wybranych dokumentów unijnych i umów międzynarodowych zawartych przez Unie z jej afrykańskimi partnerami, które zobowiązują Unię Europejską do współdziałania przy rozwiązywaniu konfliktów w Afryce. Autor koncentruje sie także na kwestii fragmentacji zobowiązań UE do działania w Afryce, uwypukla jej najistotniejsze elementy i wynikające z niej konsekwencje. W artykule zasugerowano, iż niezbędne jest podjecie kroków w celu ograniczenia negatywnych skutków fragmentacji oraz, ze spójność unijnych zobowiązań w tym zakresie pozwoliłaby na uporządkowanie reżimu prawnego i wzmocnienie działań Unii Europejskiej i jej państw członkowskich w Afryce. 